\title{
A Comparative Analysis of Four-Factor Model and Three-Factor Model in the Nigerian Stock Market
}

\author{
Esther Ikavbo Evbayiro-Osagie ${ }^{1} \&$ Ifuero Osad Osamwonyi ${ }^{1}$ \\ ${ }^{1}$ Department of Banking and Finance, Faculty of Management Sciences, University of Benin, Benin City, Nigeria \\ Correspondence: Ifuero Osad Osamwonyi Ph.D, Professor of Finance, Department of Banking and Finance, Faculty \\ of Management Sciences, University of Benin, Benin City, Nigeria.
}

Received: June 28, 2017

Accepted: July 26, 2017

Online Published: September 14, 2017

doi:10.5430/ijfr.v8n4p38

URL: https://doi.org/10.5430/ijfr.v8n4p38

\begin{abstract}
The study investigates if the three-factor model explains variation in expected returns of stocks on the Nigerian Stock Exchange (NSE); and also ascertains if the four-factor model explains the variation in expected returns of stocks on the NSE better than the three-factor model. The study use a sample size of 139 stocks with continuous trading on the NSE for the period January 2007 to December 2014 to construct 10 portfolios on the bases of size, value and returns. By means of multiple OLS regression analysis method with the aid of StataC13 software the analysis was done. The empirical analysis reveals that the three-factor model explains cross sectional variation in expected returns in the NSE. Also, the study shows that the size effect, value effect as well as momentum effect is present in the market. Comparing the four-factor model with three-factor model, shows that the four-factor model have better explanatory power than the three-factor model in explaining returns in the Market. It is recommended that equity investors, fund/portfolio managers and investment advisers should embed in their operational strategies the explanatory power of market beta, size and value as well as momentum on stock/portfolio returns to enable them build up trading strategies that minimize loss and maximize returns. Market regulators and policy makers should ensure appropriate measures are in place to improve market viability and liquidity in order to enhance the depth and breathe of the market.
\end{abstract}

Keywords: portfolio selection, four-factor model, three-factor model, Nigerian capital market

\section{Introduction}

Investment decision entails sacrifice that has to be borne today, that is certain to earn an expected return in the future that is uncertain. These attributes of investment indicate return and risk factors. This is a major discourse in modern finance, establishing the relationship between expected return and risk of a given investment. Adequate attempt has been made by researchers to identify factors that capture risk as well as determine returns through price of investment in the market. However, the measure of risk can be resolved and the relationship between expected return and risk for any asset can be determined by constructing general equilibrium models. Some existing theories and empirical investigations have identified factors capturing assets risk and explaining the cross-section of average asset returns in the market, such as Sharpe (1964), Lintner (1965) and Mossin, (1966). Other factor pricing models explaining risks and returns in the market include: the Arbitrage Pricing Model (APM) by Ross (1976), and Consumption Capital Asset Pricing Model (C-CAPM) by Rubinstein (1976) and Lucas (1978). The works of Osamwonyi and Asein (2012) and Ajao (2014) validate the application of CAPM in the Nigerian Stock Market. A well-known conclusion of the CAPM is that the expected excess return on an asset equals the beta of the asset times the expected excess return on the market portfolio.

However, many patterns have emerged from empirical studies (Fama and French, 1992; Carhart, 1997) which are not explained by the CAPM. Before the Fama and French three-factor model, several research studies [such as Cook and Rozeff (1984), Rosenbery, Reid \& Lanstein (1985)] have documented evidence of firm characteristics explaining the average stock returns that cannot be explained by the CAPM. These firm characteristics are firm size, earnings to price ratio $(\mathrm{E} / \mathrm{P})$, book-to-market equity ratio $(\mathrm{BE} / \mathrm{ME})$, price-to-book value $(\mathrm{P} / \mathrm{B})$ and past sales growth. Fama and French (1992) identified two additional factors of firm capitalization and book equity to market equity ratio (BE/ME). They provide evidence that size and book-to-market equity are proxy for sensitivity to risk factors in returns. Fama and French model is not an equilibrium model but it is purely empirically motivated as there is no theory to 
demonstrate the size and value factors as risk factors in returns. Though, Cochrane (2001) argues that 'asset pricing models that use portfolio returns as factors' may do well in describing asset returns, but they possibly will not be able to explain them, to some extent as 'these models leave unanswered questions of what explains the returns-based factors'.

Since the introduction of Fama and French three-factor model and Carhart four-factor model in 1992 and 1997 respectively, they (especially three-factor model) have been subject of many academic debates and empirical application particularly in the developed markets. Some authors have expressed doubts about the Fama and French three-factor model's explanation of the variations in excess portfolio returns. Firstly, Black (1993) believes that the results of Fama and French model might be the effect of data mining. This means that out-of-sample data might give different results. However, from some empirical works (Charitou and Constantinidis, 2004; Bundoo, 2011) this belief has been proved wrong. Secondly, in the same vein, the model lacks theoretical underpinning of its empirically identified risk factors. Thirdly, Kothari, Shanken and Sloan (1995) suggest "that the use of annual returns provides evidence in favour of the effect of beta". This idea was supposed by the work of Levhari and Levy (1977), Allen, Singh \& Powell, (2009:2). However, all of these do not invalidate the empirical usefulness and reliability of the three-factor model in explaining variations in excess portfolio returns. Improving on the three-factor model, Carhart (1995) developed the four-factor model by adopting the Fama and French three-factor model and included an additional factor which he referred to as the momentum factor. Fama and French (1996) elucidate that this additional momentum factor was motivated by the inability of the three-factor model to explain cross-sectional variables in returns in portfolio sorted by momentum. Therefore, the objectives of this study are to examine if the Fama and French three-factor model explains variation in expected returns of stocks on the Nigerian Stock Exchange; and to ascertain if the four-factor model explains the variation in expected returns of stocks on the Nigerian Stock Market better than the three-factor model.

\section{Review of Literature}

Risk-Return Relationship: Investment decision entails the relationship between risks and returns. This was established in the work of Osamwonyi \& Asein (2012) on risk and return relationship, where they document a positive linear relationship between risk and market returns using the CAPM in the NSE. The work of Markowtiz in 1952 on portfolio selection provides the foundation for modern capital market theory, and portfolio theory. This paved way for the Capital Asset Pricing Model (CAPM) of Sharpe (1964), and extended by Linter (1965), Mossin (1966), Fama (1965, 1970), Fama and French (1992, 1993), Carhart (1997) and more. Then, it successors the Arbitrage Pricing Theory (APT) model by Ross (1979) also provides explanation to the operation of financial markets along with Fama (1970) Efficient Market Hypothesis. These capital market theories paved way for the asset pricing theory.

Portfolio theory is mainly the use of statistical and mathematical programming techniques to derive optimal trade-offs. Mean-variance portfolio theory makes some restrictive assumptions. Firstly, it assumes that all investors are risk averse. Secondly, investors' risk/return preference can be described via a quadrate utility function. Thirdly is that the asset returns are inter-temporarily independent. Fourthly, variances/covariance is assumed constant through time, so they are calculated from historical values (Elton, Gruber, Brown \& Goetzmann, 2007).

Theoretical framework: The study employs fundamental theoretical multi-index models. Specifically, the fundamental theoretical models identify firm characteristics which are likely to explain differential sensitivity to the systematic risks and then form portfolios of stock based on the characteristics (Campbell, Lo, \& Mackinlay, 1997; Elton et al, 2007). Empirical research has shown that the theoretical models do a good job in explaining the cross section of returns. Hence, the theoretical framework for this study is built around two fundamental models. They are: the Fama and French (1993) three-factor model and the Carhart (1997) four-factor model.

The Fama and French Three-Factor Model: The three-factor model is a multifactor model developed by Fama and French in 1992. Elton et al (2007) describe Fama and French three-factor model as a 'microeconomic based risk factor that delineate risk factors in microeconomic terms specific to individual firm'. The three-factor model has wide spread acceptance and empirical success story because of its simplicity in development. Fama and French $(1992,1993)$ found that besides beta, two additional factors - size and book-to-market ratio are important in the determination of the cross section of expected stock returns. They described these three factors as risk factors. Fama and French $(1992,1993)$ in order to determine the most important proxy for risk factor used the Black, Jensen and Scholes (1972) time series regression model to study the combined roles of market beta, firm size (ME), earning to price ratio $(\mathrm{E} / \mathrm{P})$, leverage and book-to-market equity $(\mathrm{BE} / \mathrm{ME})$ in the cross section of average stock returns. They found that 'portfolios constructed to mimic risk factors related to market beta, size and book-to-market (BE/ME) 
have important impact on stock returns'. Specifically, the result from the study, shows that used alone or in combination with other variables, market beta has little information about average stock returns. Though firm size $(\mathrm{ME})$, earnings to price ratio (E/P), leverage and book-to-market equity (BE/ME) have explanatory power, however, firm size (ME) and book-to-market equity (BE/ME) perform best in explaining the cross-sectional variation in stock returns in the market. The study outcome produced the three-factor model which emphasize market beta, firm size (ME) and book-to market equity (BE/ME) in determining or explaining average stock returns. The explanatory power of the model has been tested in many developed and developing stock markets (see Fama \& French, 1992 for U.S Stock Exchange; Drew and Veeraraghavan, 2002 for Kuala Lumpur Stock Exchange; Charitou and Constantinidis, 2004 for the Japanese Stock Market; Gaunt, 2004 for Austrialian Stock Exchange; Eraslan, 2013 for Istanbul Stock Exchange; Ajao, 2014 for the Nigerian Stock Exchange) and the results provide evidence that the model has power to explain variations on excess portfolio returns. Drew and Veeraraghavan (2002) in their study using the Kuala Lumpur Stock Exchange from 1992 to 1999, report that the size and value factors identified by Fama and French explained the variation in stock returns in Malaysia and are not sampled specific. Similarly, in the work of Charitou and Constantinidis (2004), the findings reveal a significant relationship between the three risk factors and the cross-sectional variation in stock returns in the market. Ajao (2014) study for the period 2003 to 2012 reports that the size and value factors identified by Fama and French explained the variation in stock returns in Nigeria. The results further documents that the explanatory power of size (SMB) dominates the explanatory power of book-to-market equity (HML) in the market.

Carhart's (1997) Four-Factor Model: Carhart (1995, 1997) developed the four-factor model by adopting the Fama and French three-factor model and included an additional factor called the momentum factor. This additional factor captured is the Jegadeesh and Titman's (1993) one-year momentum effect. Fama and French (1996) elucidate that this additional momentum factor was motivated by the inability of the three-factor model to explain cross-sectional variables in returns in portfolio sorted by momentum. The four-factor model is "consistent with a model of market equilibrium with four risk factors". On the other hand, it may be "interpreted as a performance attribution model, where the coefficients and premia on the factor-mimicking portfolios indicate the proportion of mean return attributable to four elementary strategies: high versus low beta stocks, large versus small market capitalization stocks, value versus growth stocks, and one-year return momentum versus contrarian stocks" (Carhart, 1997:61). The momentum factor is the difference in returns between a portfolio of winners and a portfolio of losers.

Hong, Lim and Stein (2000), Jegadeesh (1990), Jegadeesh and Titman (1993, 2001), and Nijman et al (2004) examined momentum returns of firm size and value. The findings show that momentum effect is more in small cap stocks in the respective markets studied. Jegadeesh (1990) studied the New York Stock Exchange (NYSE) and found that stocks that have performed well over the past few months tend to make high returns over the next months, while stocks that have performed poorly over the past few months, tend to make low returns over the next months. In a follow-up study, Jegadeesh and Titman (1993) examined the NYSE and AMEX for the period from 1965 to 1989 by investigating the momentum effect of three size groups based on market value and momentum. The results obtained show that for each of the three groups there were significant excess returns. Similarly, Carhart (1997) investigated momentum for a sample of mutual funds companies. The results indicate that the momentum factor was statistically significant along with the size and value factors. Subsequently, Hong et al (2000), investigated return momentum effect on the basis of size. Nonetheless, they found that portfolio of stocks with the highest market value has non-existent of momentum effect. In another study by Jegadeesh and Titman (2001), they divided the sample into two groups of small and large cap based on the medium market capitalization. Their findings show that momentum effect is more pronounce for small cap stocks. This again confirms the results of their earlier study. Nijman et al (2004) in their study of the European stock market also investigated momentum effect on the basis of size and value along with the country, industry and individual momentum effects. Specifically their results indicate that momentum effect is more for small growth stocks. However, Bartens and Hassan (2009) in their study on the South African Stock Exchange conclude that the relationship between momentum, size and value effect and the cross-section of common stocks returns is unstable. Furthermore, Bali, Brown, and Demirtas, (2011) as well as Israel and Moskowitz (2013) in their respective studies in the stock markets document momentum effect in every size group across the markets studied.

Portfolio Construction Procedure: Fama and French in their model constructed representing portfolio to help capture of some variables in their model. They divided the market using two means - size and book-to-market ratio. Size is defined as market capitalization that is, the total market value of equities. The market is divided into two groups by size: group 1 and group 2 using the median size. The book-to-market ratio is the book equity to market equity of all stocks in the market. Here, they divided the market into three groups, defining the break points at $30^{\text {th }}$ 
and $70^{\text {th }}$ percentile of all stock listed in the stock market. Based on this classification, Fama and French formed six portfolios for each year that fell into the corresponding categories of size and book-to-market ratio. While Carhart (1997) divided the market using three ways - size, book-to-market equity and one-year momentum in stock returns. The size and book-to-market equity are as defined and explained in Fama and French portfolio construction procedure. The additional factor one-year momentum returns is constructed as the equal-weight average of firms with the highest 30 percent eleven-months returns lagged one month minus the equal-weight average of firms with lowest 30 percent eleven-month returns lagged one month. Based on the classification, more portfolios were constructed in addition for each year that fell into the corresponding categories of size, book-to-market ratio and one-year momentum is stock returns.

Furthermore, Fama and French and Carhart explain returns using three and four indices respectively - three or four zero investment portfolio that proxy as risk factors. They are market factor, size factor and value factor as well as momentum factor.

- The market factor is explained in beta. It is the excess returns on the market portfolio of stock. It is formulated as total market returns minus the risk free rate $(R m-R f)$.

- The size factor is formulated as small minus big (SMB). It is defined as the difference between the average returns of the three 'small firm' portfolios and the three 'big firm' portfolios. SMB is a measure of 'size risk'. It reveals the opinion that small firms logically are "expected to be more sensitive to many risk factors' because of their undiversifiable business nature and their inability to absorb negative financial events. It is "designed to measure the additional return investors have historically received from investing in stocks of firms with relatively small market capitalization". This additional return is often referred to as the "size premium" (Fama, 1992, 1993:9).

- The value factor explains the book-to-market ratio as it is formulated as high minus low (HML). It is commonly expressed as BE/ME. It is defined as the "difference between the average returns of the two 'high BE/ME' portfolios and the two 'low BE/ME' portfolios. The value factor is constructed to measure the 'value premium' due to investors for investing in firms with high book-to-market equity values". The HML factor "suggests higher risk exposure for typical 'value' stocks (high BE/ME ratio) versus 'growth' stocks (low BE/ME ratio)" (Fama \& French, 1993:11, 1996).

- The momentum factor is formulated as winner minus losers (WML). It is constructed as the difference between the returns on the winners' portfolio and the returns on the losers' portfolio for a given set of assets.

In the portfolio construction, there is no multicollinearity, which means that the market groupings of various portfolios are uncorrelated. The Fama and French model takes the form of the following equation:

$$
R_{p t}-R_{f t}=\alpha_{p t}+\beta_{p}\left(R_{m t} R_{f t}\right)+s_{p} S M B_{t}+h_{p} H M L_{t}+\varepsilon_{p t}
$$

The four-factor model is expressed as:

$$
R_{p, t}-R_{f t}=\alpha_{p t}+\beta_{p}\left[R_{m, t}-R_{f t}\right]+s_{p}(S M B)+h_{p}(H M L)+m_{p}(W M L)_{t}+u_{p t}
$$

Where,

$R_{p t}$ - is the portfolio's $p$ return

$R_{f t^{-}}$is the risk free rate

$\alpha_{p t}$ - is the excess return of portfolio $p$

$\beta_{p}$ - is the sensitivity of $R_{p t}$ to change in market premium $\left(R_{m t}-R_{f t}\right)$

$s_{p} \quad$ - is the sensitivity of $R_{p t}$ to change in size premium (Small - Big)

$h_{p} \quad$ - is the sensitivity of $R_{p t}$ to change in value premium (High BE/ME - Low BE/ME)

$\varepsilon_{p t^{-}}$is the random noise of portfolio $p$

$m_{p}$ - is the sensitivity of $R_{p t}$ to change in momentum factor (Winner - Loser)

$S M B_{t}$ - means Small minus Big

$H M L_{t}$ - means High minus Low

$W M L=$ means Winner minus Loser 
Carhart (1995) documents that estimate from the four-factor model often differ, however, due to significantly loadings on the one-year momentum factor. The Fama and French model and Carhart model posit that the "expected returns on a portfolio in excess of the risk-free rate are explained by the sensitivity of its returns to the three and four factors respectively.

Based on the review above, it is obvious that most studies applying Fama and French three factor model and Carhart four-factor model are predominantly carried out in developed markets like US and Australian and some emerging markets like Asian, Kenya and South Africa. However, studies investigating cross-section of returns with the application of Fama and French three factor model and four-factor model by Carhart have not be fully and predominantly done in the Nigerian Stock Market which is a classical example of an African emerging market. Hence there is little knowledge and lack of empirical evidence on the application and comparison of three-factor model and four-factor model on the cross-section of stock returns in the Nigerian Stock Market. Therefore, this study investigates the following null hypotheses:

$\mathrm{H}_{0} 1$ the Fama and French three-factor model does not explains variation in expected returns of stocks on the Nigerian Stock Exchange,

$\mathrm{H}_{0} 2$ the Carhart four-factor model does not explain the variation in expected returns on the Nigerian Stock Market better than the Fama and French three-factor model.

\section{Methodology}

The research design for this study is the longitudinal research design. The study used secondary sources of data that is panel (time series and cross-sectional) in nature. The population of interest consists of all firms whose stocks were quoted on the Nigerian Stock Exchange (NSE) between 2007 and 2014. As at January 2007, there were 212 listed firms (equities) on the NSE, while there was a total of 200 listed firms (equities) as at December 2014. The characteristics of the population that is of interest in this study are share prices, price-to-book ratio, firm capitalization and All-share index. A sample size of 139 stocks was used in the study. These are actively traded stocks based on the NSE statistics from 2007 to 2014. Actively traded stocks are stock with continuous trading on the NSE for the period 2007 to 2014. This qualifies the firm to have the needed data. However, the sample size was not the same for each year studied. Unlike previous studies, the study attempted to use large sample size which allows for all quoted stocks including newly listed companies, so as to avoid specific stock selection bias. These data were obtained from the official daily price list of the NSE and Cashcraft Asset Management Lt official website. Also, data on Treasury bill rates were obtained from the official website of the Central Bank of Nigeria (CBN). This was used as a proxy for risk-free rate of return. The 90 days Nigerian government Treasury bill rates were used to obtain the monthly risk-free rate. The obtained rates were divided by 3 to enable us estimate monthly rates.

Model Specification: This study adopts the Fama and French (1992) methodology and augmented Fama and French (1993) methodology by Cahart (1997).

The Fama and French (1993) three factor model is express in the following form:

$$
R_{p, t}-R_{f t}=\alpha_{p t}+\beta_{p}\left[R_{m, t}-R_{f t}\right]+s_{p}(S M B)+h_{p}(H M L)+\mu_{p t}
$$

The four-factor model can be expressed in the following form:

$$
R_{p, t}-R_{f t}=\alpha_{p t}+\beta_{p}\left[R_{m, t}-R_{f t}\right]+s_{p} S M B_{t}+h_{p} H M L_{t}+m_{p} W M L_{t}+\mu_{p, t}
$$

Where:

$$
R_{p, t}=\text { Average monthly and daily return of portfolio } p \text { in time } t
$$

$R_{f t}=$ Monthly or daily risk free rate

$R_{m, t}=$ Expected monthly or daily market return

$\alpha_{p t}=$ Intercept of regression

$\beta_{p}, s_{p}, h_{p}, m_{p}=$ Factor sensitivities (slope coefficient in regression)

$\mathrm{SMB}=$ Small minus big (proxy for size premium)

$\mathrm{HML}=$ High minus low (proxy for value premium)

$W M L_{t}=$ Winners minus Losers returns (Portfolio Momentum Factor)

$\mu_{p t}=$ error term

The a priori expectations of parameters to be estimated are expected to assume the following signs: 
$\alpha_{p t}<0$

$\beta_{p}>0$

$s_{p}<0$ for big firms portfolio and $>0$ for small firms portfolio

$h_{p}<0$ for value firm $\left(\right.$ high $\frac{B E}{M E}$ or low $\left.P / B\right)$ and $>0$ for growth firm $\left(\operatorname{low} \frac{B E}{M E}\right.$ or high $\left.P / B\right)$

$m_{p}<0$ for losser firms portfolio and $>0$ for winner firms portfolio

$\mu_{\mathrm{p}}>0$

Preliminary test was carried out on the data. Specifically, descriptive statistics such as mean, standard deviation, skewness, kurtosis and Jaque-Bera (JB) test were used to profile the data. Then, the data was subjected to correlation matrix and to inferential statistics. Subsequently heteroscedasticity test was done using the the Durbin-Watson test for autocorrelation. The multiple Ordinary Least Square regression (OLS) technique was used for data analysis using the StataC13 statistical and econometric software. This enables the regression output from the ten portfolios to be obtained in one output.

Measurements of Variables: The logarithmic price change was used to calculate monthly companies stock and market returns. This method was adopted because it prevents non-stationarity of the level of stock prices from affecting stock and market returns volatility \{ see Bundoo (2011), Ajao (2014)\}. It is compute as follows:

$$
\begin{gathered}
R_{i}=\ln \left(\frac{P_{i}}{P_{0}}\right) \times 100 \\
R_{m}=\ln \left(\frac{A S I}{A S I_{t-1}}\right) \times 100
\end{gathered}
$$

Where,

$R_{i}, R_{m}=$ monthly stock return, market returns

$P_{i}, A S I=$ stock prices and ASI at the end of the present month

$P_{0}, A S I_{t-1}=$ stock prices and ASI at the end of the pervious month

ln = natural logarithm

Size and Value Classification: This methodology used by Fama and French (1993) requires that the stocks be divided into classes according to size and value.

Size Classification: The stocks were divided into two classes on the basis of Market capitalization: Small Size Portfolios (stocks of small market equity) and Big Size Portfolios (stocks of big market equity).

Value (Price-to-Book $-P / B$ ) Classification: The stocks was ranked and classified into three groups following the $P / B$ ratio. The first group created is called High $\mathrm{P} / \mathrm{B}$ (also called low BE/ME) - consists of all companies that were above 70 percent of the overall market $\mathrm{P} / \mathrm{B}$ median. The second group is called the Medium P/B ratio, and it is made up of between 70 percent and 50 percent of the overall market $\mathrm{P} / \mathrm{B}$ median. The last group is referred to as the Low $\mathrm{P} / \mathrm{B}$ ratio (also called High BE/ME) - consists of all companies that were below $50 \%$ of the overall market P/B median. Also, the price-to-book ratio (P/B) rather than book-to-market equity (BE/ME) was used to separate stocks into high and low value portfolios. The use of $\mathrm{P} / \mathrm{B}$ is based on the popularity and easy of accessing this information by equity investors. Fama and French (1993) posit that the split of stocks into these different categories (two ME groups \& three BE/ME groups) was arbitrary. Arguing further, they say that there are no reasons why the test would be sensitive to this choice. Drawing from this argument and on the basis of two MC and three P/B groups, we constructed six portfolios: SL, SM, SH, BL, BM and BH. Where:

SL - all stocks in the small market capitalization group that are also in the low P/B group

SM - all stocks in the small market capitalization group that are also in the medium P/B group

SH - all stocks in the small market capitalization group that are also in the high $\mathrm{P} / \mathrm{B}$ group

BL - all stocks in the large market capitalization group that are also in the low $\mathrm{P} / \mathrm{B}$ group

BM - all stocks in the large market capitalization group that are also in the medium P/B group

BH - all stocks in the large market capitalization group that are also in the high P/B group 
Momentum Classification: Borrowing from the work of Jegadeesh and Titman (1993), and Carhart (1997) the momentum portfolios were constructed, the stocks were divided into two groups on the basis of cumulative monthly returns. Namely: the price gainers/winners (also called good performer) (PW) and the price losers (poor performer) (PL). Price Winners (PW) comprises companies with positive annual stock returns and Price losers (PL) consist of all companies with negative annual stock returns. Then, the monthly return on the momentum portfolio was estimated for a given period (January of year $t+1$ to December of year $t+1$ ). The portfolios were rebalanced on the basis of size after every year and then on the basis of past cumulative returns. On the basis of two size and two return groups, we constructed four portfolios: BPW, BPL, SPW and SPL. Where:

BPW - all stocks in the large market capitalization group that are also in the price winners group

BPL - all stocks in the large market capitalization group that are also in the price losers group

SPW - all stocks in the small market capitalization group that are also in the price winners group

SPL - all stocks in the small market capitalization group that are also in the price losers group

A total of ten portfolios were constructed based on market capitalization, price to book and price winners and losers criteria for this study.

In summary,

- The portfolio monthly return $\left(\mathrm{R}_{\mathrm{pt}}\right)$ is the value-weighted return of all stock in the portfolio. It is estimated as

$$
R_{p t}=\sum_{t=1}^{n} W i, t * R i, t
$$

Where, $\mathrm{R}_{\mathrm{pt}}=$ Monthly portfolio $\mathrm{p}$ return

$W i, t=$ Weight of stock $\mathrm{i}$ in the portfolio (market value MV of stock i/total MV portfolio)

$R i, t=$ stock i return in time $\mathrm{t}$

$n=$ the number of stocks in portfolio $\mathrm{p}$

- SMB: SMB for each month represents the difference between each month average returns of small MC group and big $\mathrm{MC}$ group. It can be mathematically expressed as:

$$
S M B=1 / 3(S L+S M+S H)-1 / 3(B L+B M+B H)
$$

- HML: HML for each month represents the difference between each month's average returns rate of high $\mathrm{P} / \mathrm{B}$ group and low $\mathrm{P} / \mathrm{B}$ group. Mathematically, it is expressed as:

$$
H M L=1 / 2(B H+S H)-1 / 2(B L+S L)
$$

- $W M L$ : WML for each month represents the difference between each month average stock returns of price winners group and price losers group. It is estimated as:

$$
W M L=1 / 2(B W+S W)-1 / 2(B L+S L)
$$

\section{Data Analysis and Interpretation}

Portfolios Formation: Table 1 shows the number of stocks used for portfolios formation and in the portfolio formed on a yearly basis from 2007 to 2014 .

Table 1. Number of stocks for portfolio formation and in portfolios formed

\begin{tabular}{lccccccccccc}
\hline Year & Sample Size & SL & SM & SH & BL & BM & BH & BPW & BPL & SPW & SPL \\
\hline $2007 / 2008$ & 99 & 16 & 11 & 22 & 5 & 6 & 38 & - & - & - & - \\
$2008 / 2009$ & 116 & 13 & 8 & 37 & 15 & 7 & 35 & 11 & 36 & 24 & 27 \\
$2009 / 2010$ & 132 & 26 & 12 & 28 & 9 & 7 & 49 & 15 & 51 & 2 & 61 \\
$2010 / 2011$ & 136 & 26 & 12 & 30 & 4 & 6 & 58 & 42 & 23 & 13 & 42 \\
$2011 / 2012$ & 133 & 22 & 10 & 45 & 9 & 9 & 57 & 12 & 48 & 10 & 42 \\
$2012 / 2013$ & 139 & 20 & 13 & 48 & 11 & 12 & 59 & 31 & 29 & 15 & 26 \\
$2013 / 2014$ & 135 & 27 & 13 & 27 & 6 & 5 & 58 & 57 & 7 & 17 & 28 \\
Total & & $\mathbf{1 3 0}$ & $\mathbf{7 9}$ & $\mathbf{2 3 7}$ & $\mathbf{5 9}$ & $\mathbf{5 2}$ & $\mathbf{3 5 4}$ & $\mathbf{1 6 8}$ & $\mathbf{1 9 4}$ & $\mathbf{8 1}$ & $\mathbf{2 2 6}$ \\
Mean & & $\mathbf{1 8}$ & $\mathbf{1 1}$ & $\mathbf{3 4}$ & $\mathbf{8}$ & $\mathbf{7}$ & $\mathbf{5 0}$ & $\mathbf{2 8}$ & $\mathbf{3 2}$ & $\mathbf{1 3}$ & $\mathbf{3 7}$ \\
\hline
\end{tabular}

Source: Authors computation (2015) 
A look at Table 1 shows the number of sampled stocks used to build portfolio for each year. The change in the sample clearly shows that this study allowed for more companies rather than using specific stocks in the formation of portfolios. The initial years represent years of portfolio formation while the later years were used for portfolio returns evaluation (2007/2008). This method was considered more realistic as most portfolio formations are done at year end using end-of-year market capitalization and price-to-book value as overall median benchmarks. It also shows the number of stocks in each of the ten portfolios constructed for each year of the sampled period. As observed, small stock portfolios (consisting of SL, SM and SH) had a total of 446 stocks with 64 stocks on the average annually. This is similar in number to the big stock portfolios (consisting of BL, BM and $\mathrm{BH}$ ) with total of 465 stocks with an average of 66 stocks annually. In the case of Price-to-Book (P/B) value, three portfolios High P/B (low BE/ME), Low P/B (High BE/ME) and Medium P/B have average stock of 84, 18 and 26 stocks respectively. The portfolio with the largest number of companies is $\mathrm{BH}$ with 345 stocks while the portfolios with the least number of companies are BM and BL with 52 and 59 stocks correspondingly. This shows that big size stocks tended to have high P/B ratios in the NSE. It can therefore be said that big companies in Nigeria are not often traded at cheap or medium stock prices when compared to their book value. They are therefore expected to be profitable in the future because high P/B also called low BE/ME in Fama and French (1992) is characteristic of growth stocks. They are stocks with persistently high earnings on book value that result in high stock prices relative to book value. For the momentum portfolios, PL and PW have average stocks of 69 and 41 respectively. It was observed that in the year 2010 and 2012 most stocks were price losers 112 and 90 respectively, especially small stocks. Columns 8 to 11 reveals that there are more price loser stocks $(n=420)$ than price winner stocks $(n=249)$ in the NSE for the period under study. Most price winners were big size firms $(\mathrm{n}=168)$. In the small firms categories there were 307 stocks with only 81 stocks as price winners. Therefore, equity portfolios in the Nigeria Stock Market can be easily built from BH $=345 ; \mathrm{SH}=237$; $\mathrm{SL}=$ $130 ; \mathrm{BPL}=194 ; \mathrm{BPW})=168$; and SPL $=226$ stocks.

Summary Statistics of Portfolios Excess Returns, Market Excess Returns, Size, Value and Momentum Factors: From Table 2, the mean returns show that excess portfolio returns from BL portfolios outperformed the big firm portfolios and the entire portfolios constructed. BL had a positive mean returns (0.002) and a standard deviation (0.273), while BH portfolio had the lowest portfolio's excess mean returns (-0.044). Among the small size portfolios, SL portfolio's excess mean returns (-0.0221) outperformed the SM (-0.028) and SH (0.040). With respect to standard deviation, all the big size portfolios (BL, BM, BH, and $\mathrm{BPW}$ ) have standard deviations that are higher than their respective small size portfolios (SL, SM, SH and SPW). These therefore mean that big size portfolios seem to offer returns with higher volatility for the period.

Table 2. Summary statistics of variables

\begin{tabular}{lccccc}
\hline \multicolumn{1}{c}{ Variables } & Mean & Std.Dev & Min & Max & Normality \\
\hline BL-Rf & 0.002 & 0.273 & -0.376 & 2.032 & 0.00 \\
SL-Rf & -0.022 & 0.092 & -0.315 & 0.387 & 0.00 \\
SH-Rf & -0.040 & 0.047 & -0.187 & 0.102 & 0.00 \\
BH-Rf & -0.044 & 0.012 & -0.522 & 0.250 & 0.00 \\
BM-Rf & -0.008 & 0.014 & -0.317 & 0.601 & 0.00 \\
SM-Rf & -0.028 & 0.079 & -0.230 & 0.466 & 0.00 \\
BPW-Rf & -0.028 & 0.061 & -0.180 & 0.103 & 0.96 \\
BPL-Rf & -0.030 & 0.119 & -0.353 & 0.251 & 0.00 \\
SPW-Rf & -0.023 & 0.079 & -0.159 & 0.279 & 0.00 \\
SPL-Rf & -0.033 & 0.070 & -0.128 & 0.301 & 0.00 \\
SMB & -0.031 & 0.212 & -1.592 & 0.117 & 0.00 \\
HML & -0.032 & 0.149 & -1.028 & 0.177 & 0.00 \\
WML & 0.005 & 0.083 & -0.403 & 0.210 & 0.00 \\
Rm-Rf & -0.024 & 0.081 & -0.324 & 0.371 & 0.00 \\
\hline
\end{tabular}

Source: Author's Computation (2015) with StataC 13

Considering the explanatory variables, market beta ( $\mathrm{Rm}-\mathrm{Rf}$ ) has negative mean value of -0.024 , which could be explained by the bearish nature of the NSE during the period under review. The size factor, SMB also had a negative mean value $=-0.0317$, implying that there was size effect on the average. The price-to-book value factor, HML again has negative mean value $=-0.0329$, showing the presence of value effect on the average. Similarly, the momentum 
factor, WML had positive mean value $=0.0059$, showing the presence of momentum effect in the market on the average. The range of variation between the minimum and maximum values is reasonably low for the number of observations (84) considered. On the basis of normality using skewness and kurtosis, all variables except BPW were normally distributed at $1 \%$ level of significance.

Correlation Analysis of Market Excess Returns, Size, Value and Momentum Factors: The results obtained are presented in Table 3.

Table 3. Correlation structure of the explanatory variables

\begin{tabular}{lrccc}
\hline & SMB & HML & WML & Rm-Rf \\
\hline SMB & 1.00 & & & \\
HML & 0.24 & 1.00 & & \\
WML & 0.01 & 0.18 & 1.00 & 1.00 \\
Rm-Rf & -0.10 & -0.31 & -0.43 & \\
\hline
\end{tabular}

Source: Authors Computation, (2015) with StataC 13

Table 3 shows that size risk (SMB) factor had a weak positive correlation with value factor $(\mathrm{HML}=0.24)$ and momentum factor $(\mathrm{WML}=0.01$ ). On the other hand the size factor had a weak negative correlation with Market Beta $(\mathrm{Rm}-\mathrm{Rf}=-0.10)$. In the case of value factor (HML), there was a weak positive correlation with momentum factor $(\mathrm{WML}=0.18)$ and a weak negative correlation with Market Beta $(\mathrm{Rm}-\mathrm{Rf}=-0.31)$. Momentum risk factor (WML) had a weak negative correlation with Market Beta $(\mathrm{Rm}-\mathrm{Rf}=-0.43)$. The positive correlation between the monthly SMB size factor and HML value factor corroborates the findings of Fama and French (1993), Charitou and Constantinidis (2004) and Ajao (2014) who documented negative correlation between SMB and HML of BE/ME values. The results show that all three risk factors were weakly correlated. This implies that Fama and French's extension of CAPM was relevant and the Carhart's momentum factor extension to Fama and French's three factor model was also important. It means that there is the absence of perfect multicolinearity since the four explanatory variables are not highly correlated.

Fama and French Three-factor Model: The Fama and French three factor regression results for ten portfolios are presented in the Table 4.

Table 4. Fama and French Three-Factor Model Multiple Regression Results

\begin{tabular}{lccccc}
\hline $\begin{array}{l}\text { Portfolio } \\
\text { Excess } \\
\text { Returns }\end{array}$ & $\begin{array}{c}\text { Constant } \\
\text { Coefficient }\end{array}$ & $\begin{array}{c}\text { Market Beta } \\
\text { Coefficient }\end{array}$ & $\begin{array}{c}\text { SMB } \\
\text { Coefficient }\end{array}$ & $\begin{array}{c}\text { HML } \\
\text { Coefficient }\end{array}$ & R-Squared \\
\hline $\begin{array}{l}\text { BL-Rf } \\
\text { P-value }\end{array}$ & -0.04 & 0.40 & -0.19 & -1.53 & 0.86 \\
& $(0.97)$ & $(0.01)^{*}$ & $(0.00)^{*}$ & $(0.00)^{*}$ & \\
$\begin{array}{l}\text { SL-Rf } \\
\text { P-value }\end{array}$ & 0.00 & 0.88 & 0.06 & -0.04 & 0.64 \\
& $(0.00)^{*}$ & $(0.00)^{*}$ & $(0.03)^{* *}$ & $(0.36)$ & \\
SH-Rf & 0.20 & 0.42 & 0.04 & 0.00 & 0.53 \\
P-value & $(0.00)^{*}$ & $(0.00)^{*}$ & $(0.02)^{*}$ & $(0.84)$ & \\
BH-Rf & -0.01 & 0.87 & -0.16 & 0.41 & 0.43 \\
P-value & $(0.23)$ & $(0.00)^{*}$ & $(0.00)^{*}$ & $(0.00)^{*}$ & \\
BM-Rf & 0.00 & 1.06 & -0.36 & 0.06 & 0.71 \\
P-value & $(0.41)$ & $(0.00)^{*}$ & $(0.00)^{*}$ & $(0.34)$ & \\
& & 0.76 & 0.09 & -0.07 & 0.71 \\
SM-Rf & -0.00 & $0.00)^{*}$ & $(0.00)^{*}$ & $(0.05)^{* *}$ & \\
P-value & $(0.09)^{* * *}$ & $(0.00)$ & & \\
\hline
\end{tabular}




\begin{tabular}{lcclll} 
BPW-Rf & -0.01 & 0.53 & -0.61 & 0.10 & 0.50 \\
P-value & $(0.01)^{*}$ & $(0.00)^{*}$ & $(0.01)^{*}$ & $(0.00)^{*}$ & \\
& & & & & \\
BPL-Rf & 0.00 & 1.10 & 0.02 & 0.10 & 0.51 \\
P-value & $(0.94)$ & $(0.00)^{*}$ & $(0.60)$ & $(0.15)$ & \\
SPW-Rf & -0.04 & -0.04 & -0.04 & -0.04 & 0.21 \\
P-value & $(0.00)^{*}$ & $(0.00)^{*}$ & $(0.00)^{*}$ & $(0.00)^{*}$ & \\
& & & & & \\
SPL-Rf & -0.01 & 0.69 & 0.03 & -0.02 & 0.66 \\
P-value & $(0.00)^{*}$ & $(0.00)^{*}$ & $(0.12)$ & $(0.46)$ & \\
\hline
\end{tabular}

Source: Author's Computation (2015) with Stata C 13

NB: $*, * * \& * * *$ represent significance at $1 \%, 5 \%$ and $10 \%$ respectively.

The alpha coefficients of all the ten portfolios are negative and are not different from zero. The coefficient for SL $(\alpha=0.00)$, SH $(\alpha=0.20)$, BPW $(\alpha=-0.01)$, SPW $(\alpha=-0.04)$, and SPL $(\alpha=-0.01)$ portfolios are statistically significant at $1 \%$, while SL and SH portfolios are positive the others are negative. This indicates the presence of abnormal returns (however not substantial) on the NSE during the period under consideration. The market factor coefficients are positive and close to 1 for all ten portfolios and all are statistically significant (that is different from zero) at $1 \%$ level except SPW that is negative. It can be interpreted to mean that increase in the market factor would lead to significant increase in excess returns from all portfolios except SPW portfolio, therefore all stocks in the ten portfolios irrespective of size generally move with the market. For the size factor coefficient, they take positive values in five out of the ten portfolios. All small size portfolios have positive coefficients which are statistically significant at different levels (1\% and 5\%), signaling a direct relationship between the portfolio returns of all small stock and the excess portfolios returns. All price winner portfolios have positive and statistically significant (at $1 \%$ level) coefficients, again signaling a direct relationship between the portfolio returns of all price gainer stocks and the portfolio excess returns. The big size portfolios all have statistically significant (at $1 \%$ level) negative coefficients. These negative relationships indicate that the returns of the big portfolios are inversely related to that of the excess market returns. All price loser portfolios have negative size factor coefficients, although not statistically significant at any level. These findings are consistent with Fama and French (1996) who show that small firms load positively and big firms load negatively on SMB factor.

In the case of price to book (P/B) value factor coefficients, five out of the ten portfolios are statistically significant at different levels. BL, BH, BPW and SPW portfolios are statistically significant at $1 \%$ while SM is statistically significant at 5\%. Beside SH, BH, BM, BPW and BPL portfolios have positive factor loading on the HML, while only BH and BPW are statistically significant. This implies that in addition to the direct relationship between these portfolios HML coefficients and portfolios excess returns, low P/B portfolios (also high BE/ME portfolios) are however associated with distress due to consistently low earnings on book value which will result in low stock prices eventually . On the other hand, SL, BL, SM, SPW and SPL portfolios are associated with negative factor loading on the HML indicating an inverse relationship with portfolio excess returns. The high P/B portfolios (also low BE/ME portfolios) are characterized as growth stocks with persistently high earnings on book value that result in high stock prices. The findings are partly consistent with Fama and French (1996) who found that high BE/ME firms load positively and low BE/ME firms load negatively on HML factor.

All the three risk factors are statistically significant in BL, BH, BPW and SPW portfolios at $1 \%$ significance levels and for SM portfolio at $1 \%$ and $5 \%$ significant levels. The explanatory power of the model is further supported by the value of the coefficient of determination (R-squared) which ranges from 0.21 to 0.86 with an average of 0.57 . Therefore, on the average $57.6 \%$ systematic variation in portfolios returns on the NSE is jointly explained by alpha coefficient, market, size and value factors. The model most explains the systematic variation in BL portfolio with R-squared of $86 \%$ and the least explained is the SPW portfolio with R-squared of $21 \%$.

Carhart Four-Factor Model: In order to test if the inclusion of momentum risk factor in the Fama and French three-factor model improved the explanatory power of the model, the Carhart four-factor model is determined and explained. From table 5, it is observed that the alpha coefficients of all the ten portfolios are negative and are not different from zero except for BM portfolio with positive alpha coefficient. The constant coefficient of BL $(\alpha=-0.04)$, SL $(\alpha=-0.00)$, SH $(\alpha=-0.02)$ and SPL $(\alpha=-0.01)$ portfolios are statistically significant at $1 \%$ and SM $(\alpha=-0.01)$ portfolio statistically significant at $5 \%$. 
Table 5. Carhart Four-Factor Model Multiple Regression Results

\begin{tabular}{|c|c|c|c|c|c|c|}
\hline $\begin{array}{c}\text { Portfolio } \\
\text { Excess } \\
\text { Returns } \\
\end{array}$ & $\begin{array}{c}\text { Constant } \\
\text { Coefficient } \\
\text { A } \\
\end{array}$ & $\begin{array}{c}\text { Market Beta } \\
\text { Coefficient } \\
\text { B } \\
\end{array}$ & $\begin{array}{c}\text { SMB } \\
\text { Coefficient } \\
s_{p} \\
\end{array}$ & $\begin{array}{c}\text { HML } \\
\text { Coefficient } \\
h_{p} \\
\end{array}$ & $\begin{array}{c}\text { WML } \\
\text { Coefficient } \\
m_{p} \\
\end{array}$ & R-Squared \\
\hline BL-Rf & -0.04 & 0.50 & -0.18 & -1.53 & 0.21 & 0.86 \\
\hline P-value & $(0.00)^{*}$ & $(0.00) *$ & $(0.00)^{*}$ & $(0.00)^{*}$ & $(0.18)$ & \\
\hline $\begin{array}{l}\text { SL-Rf } \\
\text { P-value }\end{array}$ & $\begin{array}{c}-0.00 \\
(0.00)^{*}\end{array}$ & $\begin{array}{c}0.79 \\
(0.00)^{*}\end{array}$ & $\begin{array}{l}0.06 \\
(0.03)^{* *}\end{array}$ & $\begin{array}{l}-0.03 \\
(0.42)\end{array}$ & $\begin{array}{c}-0.19 \\
(0.02)^{* *}\end{array}$ & 0.67 \\
\hline $\begin{array}{l}\text { SH-Rf } \\
\text { P-value }\end{array}$ & $\begin{array}{c}-0.02 \\
(0.00)^{*}\end{array}$ & $\begin{array}{c}0.44 \\
(0.00)^{*}\end{array}$ & $\begin{array}{l}0.04 \\
(0.02)^{* *}\end{array}$ & $\begin{array}{l}0.00 \\
(0.90)\end{array}$ & $\begin{array}{c}0.06 \\
(0.22)\end{array}$ & 0.54 \\
\hline $\begin{array}{l}\text { BH-Rf } \\
\text { P-value }\end{array}$ & $\begin{array}{c}-0.01 \\
(0.23)\end{array}$ & $\begin{array}{c}0.85 \\
(0.00)^{*}\end{array}$ & $\begin{array}{l}-0.16 \\
(0.00)^{*}\end{array}$ & $\begin{array}{l}0.41 \\
(0.00)^{*}\end{array}$ & $\begin{array}{l}-0.04 \\
(0.78)\end{array}$ & 0.43 \\
\hline $\begin{array}{l}\text { BM-Rf } \\
\text { P-value }\end{array}$ & $\begin{array}{l}0.00 \\
(0.44)\end{array}$ & $\begin{array}{l}0.99 \\
(0.00)^{*}\end{array}$ & $\begin{array}{l}-0.36 \\
(0.00)^{*}\end{array}$ & $\begin{array}{l}0.06 \\
(0.29)\end{array}$ & $\begin{array}{l}-0.16 \\
(0.16)\end{array}$ & 0.72 \\
\hline $\begin{array}{l}\text { SM-Rf } \\
\text { P-value }\end{array}$ & $\begin{array}{l}-0.01 \\
(0.05)^{* *}\end{array}$ & $\begin{array}{l}0.67 \\
(0.00)^{*}\end{array}$ & $\begin{array}{l}0.08 \\
(0.00)^{*}\end{array}$ & $\begin{array}{l}-0.06 \\
(0.05)^{* *}\end{array}$ & $\begin{array}{l}-0.21 \\
(0.00)^{*}\end{array}$ & 0.75 \\
\hline $\begin{array}{l}\text { BPW-Rf } \\
\text { P-value }\end{array}$ & $\begin{array}{l}-0.01 \\
(0.72)\end{array}$ & $\begin{array}{l}0.70 \\
(0.00)^{*}\end{array}$ & $\begin{array}{l}-0.05 \\
(0.00)^{*}\end{array}$ & $\begin{array}{l}0.09 \\
(0.00)^{*}\end{array}$ & $\begin{array}{l}0.39 \\
(0.00)^{*}\end{array}$ & 0.73 \\
\hline $\begin{array}{l}\text { BPL-Rf } \\
\text { P-value }\end{array}$ & $\begin{array}{l}-0.00 \\
(0.72)\end{array}$ & $\begin{array}{l}0.74 \\
(0.00)^{*}\end{array}$ & $\begin{array}{l}0.01 \\
(0.72)\end{array}$ & $\begin{array}{l}0.13 \\
(0.00)^{*}\end{array}$ & $\begin{array}{l}-0.82 \\
(0.05)^{*}\end{array}$ & 0.78 \\
\hline $\begin{array}{l}\text { SPW-Rf } \\
\text { P-value }\end{array}$ & $\begin{array}{l}-0.00 \\
(0.33)\end{array}$ & $\begin{array}{c}0.64 \\
(0.00)^{*}\end{array}$ & $\begin{array}{c}0.10 \\
(0.00)^{*}\end{array}$ & $\begin{array}{c}0.02 \\
(0.65)\end{array}$ & $\begin{array}{c}0.56 \\
(0.00)^{*}\end{array}$ & 0.51 \\
\hline $\begin{array}{l}\text { SPL-Rf } \\
\text { P-value }\end{array}$ & $\begin{array}{c}-0.01 \\
(0.00)^{*}\end{array}$ & $\begin{array}{c}0.60 \\
(0.00)^{*}\end{array}$ & $\begin{array}{c}0.03 \\
(0.12)\end{array}$ & $\begin{array}{l}-0.01 \\
(0.56)\end{array}$ & $\begin{array}{l}-0.21 \\
(0.00)^{*}\end{array}$ & 0.71 \\
\hline
\end{tabular}

Source: Author's Computation (2015) with StataC 13

$\mathrm{NB}: *, * * \& * * *$ represent significance at $1 \%, 5 \%$ and $10 \%$ respectively.

The market risk factor coefficients are positive and close to 1 for all ten portfolios and are all statistically significant at $1 \%$ level. It can be interpreted to mean that an increase in market factor would lead to a significant increase in excess returns in all portfolios. For the size risk factor coefficient, they take positive values in six out of the ten portfolios. All small size portfolios have positive size coefficients which are statistically significant, where the SM portfolio is significant at $1 \%$, the SL and SH portfolios are significant at 5\%. The SPW portfolio also has positive statistically significant (at $1 \%$ level) coefficient. This signals a direct relationship between the portfolio returns of small stocks and the portfolio excess returns. The big size portfolios (BL, BH, BM and BPW) all have highly statistically significant negative coefficients (at $1 \%$ level). All price loser portfolios have negative SMB coefficient which was not statistically significant at any level. In the value risk factor $(\mathrm{P} / \mathrm{B})$ coefficients, five out of the ten portfolios are statistically significant at different levels. BL, BH, BPW and SPW portfolios are statistically significant at $1 \%$ while SM is statistically significant at $5 \%$. Beside $\mathrm{SH}, \mathrm{BH}, \mathrm{BM}, \mathrm{BPW}$ and BPL portfolios have positive factor loading on the HML, where only BH and BPW are statistically significant. On the other hand, SL, BL, SM, SPW and SPL portfolios are associated with negative factor loading on the HML indicating an inverse relationship with portfolio excess returns.

The momentum risk factor (WML) coefficients are different from zero except for SH and BH portfolios. They are statistically significant in six of the ten portfolios at different levels. For SM, BPL, SPL, BPW and SPW portfolios, 
WML coefficients are statistically significant at $1 \%$ level while SL is statistically significant at $5 \%$. Beside the price winner (BPW and SPW) portfolios along with BL and SH portfolios have positive factor loading on the WML factor, where only the price winner (BPW and SPW) portfolios are statistically significant. This implies that in addition to the direct relationship between these portfolios' WML coefficients and portfolios excess returns, stocks with immediate past positive returns outperformed past losers irrespective of size. On the other hand, BL, BH, SL, SM, BPL and SPL portfolios are associated with negative factor loading on the HML indicating an inverse relationship with portfolio excess returns. All four factors were significant in BPW and SM portfolios at $1 \%$ and 5\% level respectively. The robustness of the model is further supported by the value of the coefficient of determination (R-squared) which ranges from 0.43 to 0.86 with an average of 0.676 . Therefore, on the average there is $67.6 \%$ systematic variation in portfolios returns on the NSE which was jointly explained by alpha coefficient, market beta, size factor, value factor and momentum factor. The model highly explains the systematic variation in BL portfolio with R-squared of $86 \%$ and the least explained is the $\mathrm{BH}$ portfolio with R-squared of $43 \%$.

A number of conclusions can be drawn from the above analysis. Firstly, that the momentum factor (WML) was priced and had statistically significant effects in all the portfolios except BL, BM, BH and SH portfolios. Secondly, the momentum factor (WML) was greater in coefficient magnitude than the size (SMB) and value (HML) factors in six portfolios except BL, BM, BH and SL portfolios. The momentum factor did not dominate the market factor in any portfolio. Thirdly, that the market beta was statistically significant in affecting all portfolios group formation in Nigeria. Furthermore, in comparison with the three-factor model, we discovered major improvement in the explanatory power (adjusted $\mathrm{R}^{2}$ ) of the models which included momentum risk factors (WML) in the pricing of portfolios in the market. It increased from the range of ' $21 \%$ to $86 \%$ ' in the Fama and French model to the range of ' $43 \%$ to $86 \%$ ' in the Carhart model. Considering each portfolio, BL and BH portfolios remained the same at $86 \%$ and $43 \%$ respectively. Then, SL portfolio improved from $64 \%$ to $67 \%$, SH and BM improves by $1 \%$ from $53 \%$ to $54 \%$ and $71 \%$ and $72 \%$ respectively. Likewise the SM portfolio improves by $4 \%$ from $71 \%$ to $75 \%$. Importantly, the winners' portfolios BPW and SPW greatly improved by $23 \%$ (from $50 \%$ to $73 \%$ ) and $30 \%$ (from $21 \%$ to $51 \%$ ) respectively. Similarly, the losers' portfolios BPL and SPL improved greatly by $27 \%$ (from $51 \%$ to $78 \%$ ) and $5 \%$ (from $66 \%$ to $71 \%$ ) respectively. This therefore means that momentum factor is needed to improve the pricing of equity securities and it represents valuable information to investors in the NSE. So, $\mathrm{H}_{2}$ (that the four-factor model does not explain the variation in expected returns on the NSE better than the three-factor model) be rejected.

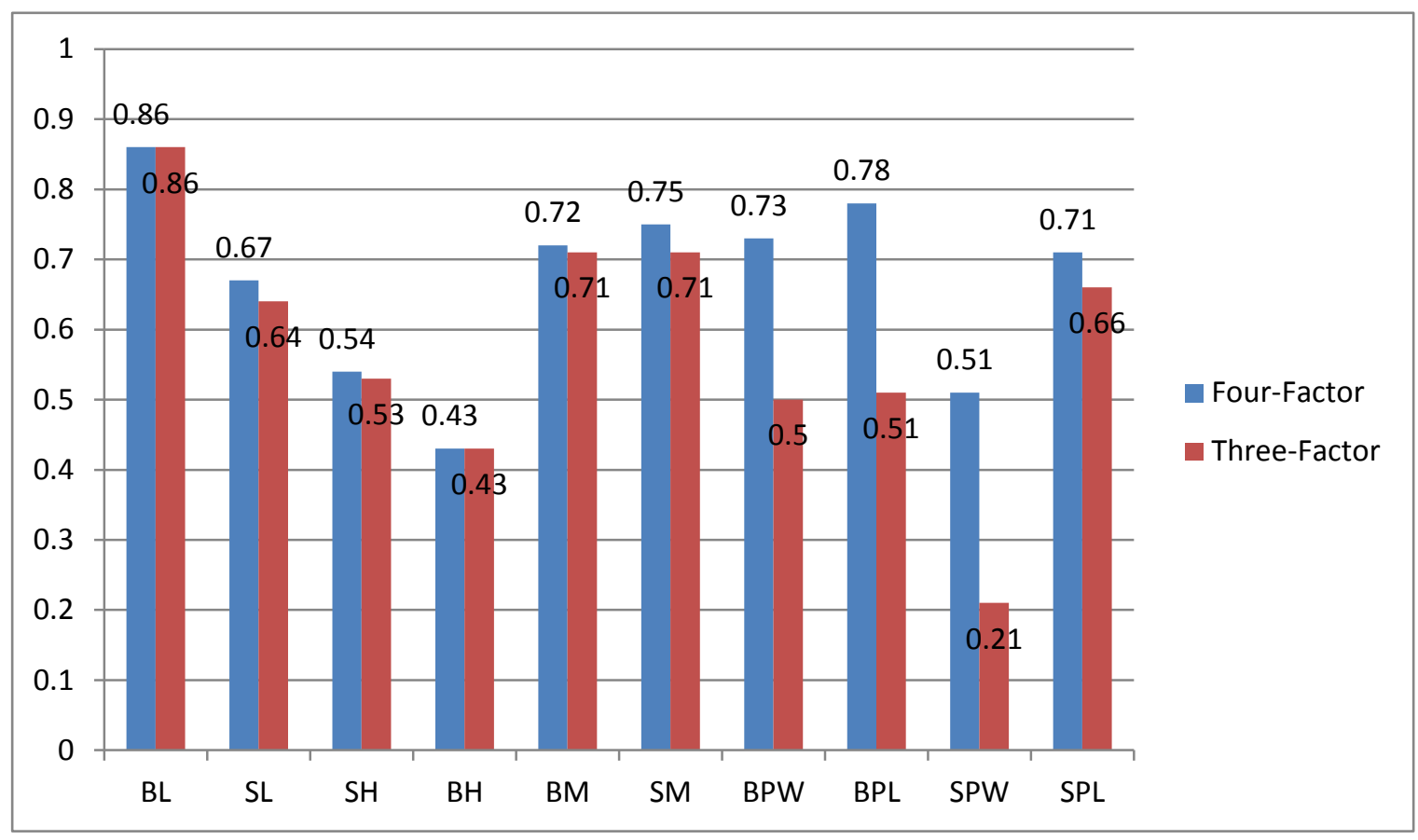

Figure 1. Four-Factor Model vs Three-Factor Model (R-Squared); Arthurs Computation, 2015 


\section{Conclusion and Recommendations}

The empirical analyses of this study reveal a number of findings which have significant implications for investors and fund/portfolio managers in particular and the market as well as the economy in general. The portfolio formation reveals that the composition of each of the ten portfolios formed is significantly affected by the number of listed stocks on the NSE which is relatively small. This is an observed general limitation in using emerging stock market data. The excess market returns ( $\mathrm{Rm}-\mathrm{Rf}$ ) has negative mean value of -0.024 over the sampled period, showing that returns from risk-free assets offer better returns than stock assets. This may be explained by the bearish mature of the market during the period under review. The market experienced financial crisis as a result of the contagion effect of the global financial meltdown between the year 2007 and 2011. The market factor was statistically significant in all ten portfolios, implying that all stocks in the ten portfolios irrespective of size generally move with the market. The mimicking portfolio for size, SMB also has a negative average return indicating that on the average, the big size firms outperformed small size firms (high capitalization stocks produced higher than average returns than lower capitalization stocks in NSE). Also, the mimicking portfolio for price to book value, HML again has negative mean value, stating that stocks with low price to book value outperformed stocks with high price to book value in both big and small size firms. Similarly, the mimicking portfolios for momentum returns, WML has positive mean value, indicating that stocks with positive returns outperformed stocks with negative returns in the Market. It is observe that all three risk factors were weakly correlated. This implies that Carhart extension of the three-factor model is important. This means that all additional three explanatory factors are independent and should be included in the pricing of excess portfolio returns in NSE. It is a confirmation of the success of the model that size, $\mathrm{P} / \mathrm{B}$ value and momentum capture common variations in portfolio returns missed by the market factor. The general empirical evidence shows that the size effect holds in this study, where the size factor was significant in almost all the portfolios. Investors holding portfolio of stocks small size will earn higher returns than investors with stocks in big size firms. Similarly, value effect is present in the market, therefore, investors that invest in value firms will generate higher returns. In the case of the momentum effect, it was statistically significant as the size and value effect. The momentum factor cannot be ignored by investors in the pricing of assets in the NSE. Investors holding portfolios of stocks that are price winners will generate superior returns than holders of portfolio of stock that are price losers. In the comparative analysis of the regression results of the standard three-factor model and four-factor model, we discovered major improvement in the explanatory power (adjusted $\mathrm{R}^{2}$ ) of the models which included momentum risk factors (WML) in the pricing of portfolios in Nigeria. As a result, momentum effect cannot be ignored as it represents valuable information to investors in the Market. In other words, market beta, firm size, value and momentum are important factors explaining stocks/portfolios returns in the market.

Based on the findings in this study and the conclusion drawn thereof, some recommendations are made. It is recommended that equity investors, fund/portfolio managers as well as investment advisers should embed in their operational strategies the explanatory power of market beta, size and value as well as momentum effects on stock/portfolio returns. This will enable them build up trading strategies that minimize loss and maximize returns. In addition, they should pay more attention to size effect as it dominates the value and momentum effects in the market. Although the three-factor and four-factor models explain a large aspect of variation in expected returns in the NSE, operators (investors, fund managers) and researchers using the model should be careful in using it in returns consideration since it does not explain in totality variation in expected returns. Market regulators and policy makers should ensure appropriate measures are in place to improve market viability and liquidity in order to enhance the depth and breathe of the market. Some appropriate measures could be daily price ceiling, promoting price speculators etc. This is pertinent due to some level of unprofitability in the NSE which has reduced the market economic viability. This was possibly occasioned by the global financial meltdown, buy and hold syndrome by investors, scantiness of stocks in the market and prohibition of speculation of securities price. Although this study contributes to the frontier of knowledge, much still needs to be done in future studies.

\section{References}

Ajao, M. G. (2014). Risk factors in assets pricing: A comparative analysis of the three factors model and the capital asset pricing model in the Nigerian Stock Exchange. Being an unpublished Ph.D thesis, in the department of Banking and Finance, University of Benin, Benin City, Nigeria.

Allen, D. E., Singh, A. K., \& Powell, R. (2009). Assets pricing, the Fama-French model and the implication of quantile regression analysis. Working paper series 0911, School of Accounting, Finance and Economics, Edith Cowan University, Joondalup. 
Banz, R. W. (1981). The relationship between return and market value of common stocks. Journal of Financial Economics, 9(1), 3-18. https://doi.org/10.1016/0304-405X(81)90018-0

Bartens, R., \& Hassan, S. (2009). Value, size and momentum portfolios in real time: The cross-section of South African stocks. Working Paper Number 154, 1-24.

Black, F. (1993). Beta and returns. Journal of Portfolio Management, 20, 8-18. https://doi.org/10.3905/jpm.1993.409462

Bundoo, S. K. (2011). An analysis of stock market anomalies and momentum strategies on the Stock Exchange of Mauritius. African Economic Research Consortium, AERC Research Paper 227, Nairobi Kenya.

Campbell, J. Y., Lo, A.W., \& MacKinlay, A. C. (1997). The Econometrics of Financial Markets, Princeton University Press.

Carhart, M. M. (1997). On the persistence in mutual fund performance. Journal of Finance, 52, 57-82. https://doi.org/10.1111/j.1540-6261.1997.tb03808.x

Central Bank of Nigeria (CBN) Statistical Bulletin. Various Issues (2005-2014).

Charitou, A., \& Constantinidis, E. (2004). Size and book-to-market factors in earnings: empirical evidence from Japan. Journal of Managerial Finance, 8, 574-594.

Cochrane, J. H. (2001). Asset Pricing. Princeton University Press.

Cook, T. J., \& Rozeff, M. S. (1984). Size and earnings/price ratio anomalies: One effect or two. Journal of Financial and Quantitative Analysis, 19, 427-466. https://doi.org/10.1111/j.1540-6288.1984.tb00545.x

Daniel, K., \& Titman, S. (1997). Evidence on the characteristics of cross-sectional variation in stock returns. Journal of Finance, 53, 1-33. https://doi.org/10.1111/j.1540-6261.1997.tb03806.x

Davis, J. (1994). The cross-section of realized stock returns: The pre-COMPUSTAT evidence. Journal of Finance, 49, 1579-1593. https://doi.org/10.1111/j.1540-6261.1994.tb04773.x

Drew, M. E., \& Veeraraghavan, M. (2002). A closer look at the size and value premium in emerging markets: Evidence from the Kuala Lumpur Stock Exchange. Asian Economic Journal, 16(1), 337-351. https://doi.org/10.1111/1467-8381.00156

Elton, E. J., Gruber, M. J., Brown, S. J., \& Goetzmann, W. N. (2007). Modern Portfolio Theory and Investment Analysis, New York, John Wiley \& Sons.

Eraslan, V. (2013). Fama and French three-factor model: Evidence from Istanbul Stock Exchange. Business and economics Research Journal, 4(2), 11-22.

Fama, E. F., \& French, K. R. (1992). The cross-section of expected stock returns. Journal of Finance, 47(2), 427-486. https://doi.org/10.1111/j.1540-6261.1992.tb04398.x

Fama, E. F., \& French, K. R. (1993). Common risk factors in the returns on stocks and bonds. Journal of Financial Economics, 33, 3-56. https://doi.org/10.1016/0304-405X(93)90023-5

Fama, E. F., \& French, K. R. (1995). Size and book to market factor in earnings and returns. Journal of Finance, 50, 131-155. https://doi.org/10.1111/j.1540-6261.1995.tb05169.x

Fama, E. F., \& French, K. R. (1996). Multifactor explanations of asset pricing anomalies. Journal of Finance, 51, 55-84. https://doi.org/10.1111/j.1540-6261.1996.tb05202.x

Gaunt, C. (2004). Size and book to market effects and the Fama French three factor asset pricing model: Evidence from Australian Stock Exchange. Accounting and Finance, 44(1), 27-44. https://doi.org/10.1111/j.1467-629x.2004.00100.x

Hon, M. T., \& Tonks, I. (2003). Momentum in the UK stock market. Journal of Multinational Financial Management. 13(1), 43-70. https://doi.org/10.1016/S1042-444X(02)00022-1

Hong, H., Lim, T., \& Stein, J. C. (2000). Bad news travels slowly: Size, analyst coverage, and the profitability of momentum strategies. Journal of Finance, 55, 265-295. https://doi.org/10.1111/0022-1082.00206

Jeegadeesh, N., \& Titman, S. (1993). Returns of buying winners and selling losers: Implications for stock market efficiency. Journal of Finance, 48, 65-92. https://doi.org/10.1111/j.1540-6261.1993.tb04702.x 
Jegadeesh, N. (1990). Evidence of predictable behavior of security returns. Journal of Finance, 45(3), 881-898. https://doi.org/10.1111/j.1540-6261.1990.tb05110.x

Kothari, S. P., Shanken, J., \& Sloan, R. G. (1995). Another look at the cross-section of expected stock returns. Journal of Finance, 50, 185-224. https://doi.org/10.1111/j.1540-6261.1995.tb05171.x

Lewellen, J. (2002). Momentum and autocorrelation in stock in stock returns. Review of Financial Studies, 15, 533-573. https://doi.org/10.1093/rfs/15.2.533

Lintner, J. (1965). The valuation of risk assets and the selection of risky investments in stock portfolios and capital budget. Review of Economics and Statistics, 47, 13-37. https://doi.org/10.2307/1924119

Lucas, R. E. (1978). Asset prices in an exchange economy. Econometrica, 46, 1429-1447. https://doi.org/10.2307/1913837

Mackinlay, A. C. (1995). Multifactor models do not explain deviation from the CAPM. Journal of Financial Economics, 38, 3-28. https://doi.org/10.1016/0304-405X(94)00808-E

Markowitz, H. (1952). Portfolio selection. Journal of Finance, 7(1), 77-99. https://doi.org/10.1111/j.1540-6261.1952.tb01525.x

Merton, R. C. (1973). An intertemporal capital asset pricing model. Econometrica, 41(5), 867-887. https://doi.org/10.2307/1913811

Mossin, J. (1966). Equilibrium in a capital asset market. Econometrica, 34(4), 768-783. https://doi.org/10.2307/1910098

Nigerian Stock Exchange (NSE) Fact Books. Various Issues (2005-2014).

Nijman, T. E., Swinkels, L. A. P., \& Verbeek, M. (2004). Do countries or industries explain momentum in Europe? Journal of Empirical Finance, 52, 2129-2144. https://doi.org/10.1016/j.jempfin.2004.02.001

Osamwonyi, I. O., \& Asein, E. I. (2012). Market risk and returns: evidence from the Nigerian capital market. Asian Journal of Business Management, 4(4), 367-372.

Rosenbery, B., Reid, K., \&Lanstein, R. (1985). Persuasive evidence of market inefficiency. Journal of Portfolio Management, 11, 9-17. https://doi.org/10.3905/jpm.1985.409007

Ross, S. A. (1976). The arbitrage theory of capital asset pricing. Journal of Economic Theory, 13, 341-360. https://doi.org/10.1016/0022-0531(76)90046-6

Sharpe, W. F. (1964). Capital asset prices: A theory of market equilibrium under conditions of risk. Journal of Finance, 19, 425-442. https://doi.org/10.1111/j.1540-6261.1964.tb02865.x 